\title{
ADAPT OR DIE?
}

SS Visser and $\mathrm{AH} \mathrm{Nel}$

\section{OPSOMMING}

As gevolg van 'n wêreldwye ekonomiese resessie het beperkte finansies 'n invloed op die beskikbare fondse van enige huishouding en is die hoop op die verbetering van medisyne en die sosio-ekonomiese omstandighede van mense maar skraal. Die Her-konstruksie- en Ontwikkelingsprogram (HOP) van Suid-Afrika stel onder andere ten doel om die lewensomstandighede van die mense te verbeter waaronder behuising, opleiding en onderwys en gesondheidsorg. Laasgenoemde blyk die grootste uitda-ging te wees aangesien dit voorkomende en bevorderende gesondheidsorg insluit. Gesondheidsorg was in die verlede onvoldoende vanwë̈ onbereikbare gesondheids-dienste moontlik vanwe ̈ die wandistribusie van gesondheidsdienste; wanverspreiding van gesondheidspersoneel, kulture en gelowe. Die uraag ontstaan hoe daar met beperkte finansies die beste omstandighede voorsien kan word? 'n Literatuurstudie is gedoen om kwaliteit gesondheidsorg en die finansiering daarvan aan te spreek en 'n empiriese ondersoek oor die bestaande gesondheidsorg en finansies is gedoen.

Daar word aanbeveel dat aanpassings gemaak moet word om te oorleef deur;

- die desentralisasie en rasionalisasie van die administrasie van gesondheidsorg.

- die beklemtoning van en die realisasie van doeltreffende en doelmatige primêre gesondheidsorg.

- die implementering van deelnemende bestuur in gesondheidsorgorganisasies.

- die voorsiening van opleiding in finansiële bestuur aan bestuurders van gesondheidsorgorganisasies

- die toepassing van bestuursrekeningkundige beginsels vir die verbete-ring van die doeltreffendheid en doelmatigheid van bestuur.

\section{ABSTRACT}

The worldwide economic recession and the concomitant limited stock of finances have had an influence on the available money of every household and have also inhibited the improvement of socio-economic conditions and medicine. The Reconstruction and Development Programme (RDP) has the objective of improving the living conditions of the people with regard to housing. education, training and health care. The latter seems to be a major problem which has to be addressed with the emphasis on the preventive and promotional aspects of health care. $A$ comprehensive health care system did not come into being properly in the past because of the maldistribution of health care services, personnel and differences in culture and health care beliefs and values. The question that now arises, is how to render a quality health care service within the constraints of inadequate financing and resources. A comprehensive literature study has been done with reference to quality health care and financing followed by a survey of existing health services and finances.

Recommendations are made about minimum requirements to be accepted if one were to adapt rather than die in terms of the provision of healthcare;

- the decentralization and rationalization of the administration of health care.

- the stress on and realization of effective and efficient primary health care.

- the acceptance of participative management in health providing organizations,

- the provision of financial management training for health care managers and

- the application of management accounting principles for the improvement of the efficiency and effectiveness of management.

\section{INTRODUCTION AND BACKGROUND}

The worldwide economic recession and the concomitant limited stock of finances have had an influence on the available money of every household and has inhibited improvement of socio-economic conditions and medicine. Director Coen Slabber contends that "Medical inflation is usually $3 \%$ higher than the normal inflation rate because of high pharmaceutical prices and the cost of imported equipment" (Anon., 1994c:26). Smith (1994:16) refers to The World Bank's recent repor "Better Health in Africa" which claims that more effective planning and management of pharmaceuticals, health sector personnel and health infrastructure and equipment need to feature high on the agenda for change.

The Reconstruction and Development Programme (RDP) of South Africa has the objective of improving the living conditions of the people with regard to housing, education, training and health care. The latter seems to be a major problem which has to be addressed with the emphasis on the preventive and promotional aspects of health care. A comprehensive health care system did not come properly into being in the past because of the maldistribution of health care services, personnel and differences in culture and health care beliefs and values.

The nearly $6.8 \%$ of Gross Domestic Product (GDP) ( \pm R21.6 billion, US \$6 billion) which South Africa spends on health is more than we can afford. The World Health Organization's target for South Africa as a developing country by the year 2000 is only $5 \%$. Put differently, $11.7 \%$ of total state income is spent on health, which is close to the average of $12.6 \%$ of developed countries (Anon. 1994b:26).

Contributions to medical aid schemes increased from R442 a year in 1982 to R4 110 in 1992, a compound annual increase of $25 \%$. At the same time, the average annual administration fee per member rose from $\mathrm{R} 31$ to R222 - a compound growth of $22 \%$ (Stewart, 1994:18). Smith (1994:16) maintains, that health care costs in South Africa have escalated at an average of around $25 \%$ annually over the past decade.

Compared to the USA, South Africa is in a weaker position because $10 \%$ of surgery in South Africa is done on an inter-day basis, with $90 \%$ requiring extended hospital stays, while $60 \%$ of surgery in the USA is carried out in day clinics (Smith, 1994:16). 
It is clear that health services in South Africa have no choice but to either adapt to survive or to die in the process.

\section{PROBLEM STATEMENT}

The North West Province (where this survey was done) one of the nine new Provinces in South Africa, has inherited a health department which provides services fragmented along racial, geographic, preventive/curative and professional lines.

It is imperative that the health services be completely replanned and restructured to reflect the new priorities of the Department and of the RDP. The paucity of information required to undertake this task will complicate the process of reorganization, and it is a factor which emphasizes the importance and urgency of setting up systems that will provide managers with the information they require to plan on an ongoing basis (Department of Health, 1995a:3).

The ANC's Reconstruction and Development Programme indicates that South Africa is spending R550 per capita on health care per annum, which is nearly 10 times as much as the World Bank estimates it should cost to provide basic public health services and essential clinic care for all, yet millions of people are even without such very basic services or care (Anon., 1994a:5). Statements such as "Health services are fragmented, inefficient and ineffective, and resources are grossly mismanaged and maldistributed" (Anon., 1994a:5) contributes to the different Provinces and the North West Province responsibilities to adapt to changes or to die.

The question that now arises is how to render a quality health care service within the constraints of inadequate financing and resources.

\section{SITUATION ANALYSIS}

The North West Province has a population of 3500000 people living in an area of 118710 square kilometres. Almost one-third of the population (1 000000 ) live in the far-eastern region of the Province (Department of Health, 1995b:1-2). Other areas where there are large concentrations of people include the Klerksdorp, Mafikeng, Taung and Rustenburg areas. The greatest sources of income in the Province are mining and agriculture, the average per capita income per month is R1 789. This figure does not, however, reflect the vast differences between the rich and the poor in the Province, and says nothing about geographical discrepancies. About $62 \%$ of the population is literate. Of the 725500 people in regular employment, $70 \%$ are employed in the private sector and $17 \%$ are employed by national, provincial and local governments.

In the Northem Transvaal the ratio of doctors to patients is 1:30 450 (Stewart, 1994:18), compared with one per 2000 of the population in South Africa at large (Smith, 1994:16).

While 161 out of every 1000 babies bom in Mali will die, South Africa with its comparative wealth, still has the highest incidence of tuberculosis in the world (Smith, 1994:16). Smith (1994:16) also contends that the incidence of measles, HIV, polio and malnutrition is disproportionately high when measured by world standards.

The decentralization of health service delivery down to district level is one of the most important changes planned by the Department (Department of Health, 1995a:7). The ANC is committed to the promotion of health through prevention and education with a Primary Health Care Approach as the underlying philosophy of the health system. It embodies the concept of community development and is based on full community participation in the planning, provision, control and monitoring of services. It aims to reduce inequalities in access to health services, especially in the rural areas and deprived communities (ANC, 1994:19).

The RDP is an integrated programme of transformation which involves the re-orientation of health priorities and the re-allocation of resources of all kinds funding, staff, equipment and facilities.

The ANC recommends the Primary Health Care (PHC) approach to the delivery of health services. Within the PHC approach, PHC itself is central and was defined in the Declaration of Alma Ata as " 'Primary Health Care' is essential health care based on practical, scientifically sound and socially acceptable methods and technology made universally accessible to individuals and families in the community through their full participation and at a cost that the community and country can afford to maintain at every stage of their development in the spirit of self-reliance and self-determination".

PHC will form an integral part of the country's National Health System (NHS), of which it will be the central focus, while the PHC approach will provide guidance within the overall social and economic development of the community (ANC, 1994:20).

\section{METHOD OF INVESTIGATION}

A comprehensive literature study has been done with reference to quality health care and financing. A survey of existing health services and finances by means of interviews conducted during committees with health care providers and other leading figures in the goveming of health care is provided.

\section{PURPOSE OF INVESTIGATION}

To make a contribution to the RDP by aiming to develop guidelines for a quality health care service by utilizing the findings of this survey.

\section{FINDINGS AND CONCLUSIONS}

The following findings and conclusions have been arrived at:

- Healthcare is inadequate - this is caused by several factors, for example maldistribution of funds, personnel and the availability of health services.

- Curative care is concentrated in urban areas and is not accessible in rural areas.

- The current formulae for subsidies are very crude, as they do not take into account the mortality rates, population, morbidity and per capita income. The current funding per capita is insufficient - provinces with academic hospitals are advantaged compared to others.

- The provision of effective primary health care is more cost effective than secondary and tertiary health care and primary health care is more accessible to the community.

- Preventive health care has become very urgent within the framework of the fact that South Africa has the highest incidence of tuberculosis in the worid, and incidences of measies, HIV (Aids), polio and malnutrition which are dispropor-tionately high by world standards, as outlined in the introduction and back ground to this paper.

- The community is not involved in the provision of primary health care.

- Current highly specialized medical and nursing personnel are providing primary health care in hospitals, while this should be done at health clinics.

- The management of health care services can be done more effectively and efficiently.

- The administration of health care services is still too centralized.

- Primary health care is inadequate and too little funding was allocated to it in the past. due to the fact that primary health care was integrated into and executed by secondary health care officers, and therefore both tertiary and secondary health care absorbed too large a proportion of the funds in the past.

- Health care managers are not equipped with the relevant financial management knowledge and competence needed to manage health care organizations effi-ciently and effectively.

- Current budgetary control is done by incremental budgets which duplicate problems encountered in the past in the subsequent year's budget. 


\section{RECOMMENDATIONS}

The following recommendations can be made

- Primary health care must be made available to the community at the ground level. The ANC's proposal of providing primary health care at Community Health Centres with a 24-hour emergency and maternity services is acceptable.

- Health education centring on tuberculosis, HIV (Aids), polio and malnutrition is crucial for purposes of improving diagnosis, treatment management, compliance and effective follow-up.

- The community must be involved in the provision of primary health care to ensure that resources are used to the best advantage of all in the community. This will be of particular interest in rural and other disadvantaged communities.

- The Regional Government's Draft White Paper on Health for the North West Province (Department of Health, 1995a:12) recommends providing for the building of new clinics and the upgrading of existing clinics for every $1000-4000$ households, and one health centre for each 3- 6 clinics. A major criterion for planning the medium term clinic infrastructure will be that at least $95 \%$ of the residents of the Province should live no further away than $5 \mathrm{~km}$ from an available clinic. People residing more than $5 \mathrm{~km}$ away from fixed clinics will be provided with a mobile clinic service.

- A new formula must be calculated to include all factors affecting the amount of money spent by determining or assessing a causal relationship between the activity and the cost. The adjustment of the RAWP (Regional Allocation Weighted Programme) formula of Great Britain can be made applicable to South African conditions.

- The management of health care must be made effective and efficient. That means both doing the right things, and doing things right. Therefore managers of health care organizations must be qualified in financial management and management accounting, which requires an improvement of the curriculum of professional medical and nursing personnel, or a provision of courses in management through in-service training.

- Developments in management accounting include participative management which can make management more effective and efficient. Kharbanda \& Stallworthy (1991:26) maintain that the Japanese are way ahead of the rest of the world in participative management, seeing that "teamwork is the crux", and that "cost is everybody's business", which philosophy has brought about better interpersonal relationships and higher productivity and cost effectiveness. Gibson et al. (1991:129) recommend participative management, seeing that it is "a concept of managing that encourages employees' participation in decision-making and matters that affect their jobs".

Participative management has the effect that the work is done by personnel who have most knowledge about that particular aspect, and in view of the fact that group decision-making is preceded by brainstorming, each member gets an opportunity to make a contribution. -Participative management also has the effect that participative budgets are compiled where more personnel are involved and at least the following portfolios are represented at a budgetary planning meeting, viz. a financial accountant for the execution of financial reporting, a management accountant for the functions of planning, control and decision-making, and professional medical and nursing personnel. - Seeing that incremental budgetary errors perpetuate themselves in budgets from the past, the institution of zero-based budgeting is essential. Although this demands more time, the principle of motivation of each item in the budget will introduce a better order or priorities in the decision-making package on an ongoing basis.

- Management by objectives can have the advantage that everyone involved in management should strive for an aim which should be the aim of all within the organization.

- The management and administration of health care should be decentralized in order to eliminate the long process involving lots of paperwork. which in the past had been very ineffective.

- Through the use of responsibility accounting and cost, profit and investment centres, management and responsibilities can be brought down to the levels of region, district and community, and a better health care service can be rendered.

- Seeing that health organizations are not profit-driven organizations, they have to break even in terms of income and expenditure, and the principle of break-even analysis will be very applicable, also in ensuring the utilization of infrastructure and human resources in the most economical way in order to provide a quality service. The application of activity-based costing ( $A B C$ ), activity-based budgeting and management and work-force activity-based management (WABM) will lead to a more equitable allocation of resources to activities which can lead to a more effective and efficient management with regard to planning, control and decision-making.

\section{RECAPITULATION}

From the above findings, conclusions and recommendations can emanate with regard to the minimum requirements to be accepted if one were to adapt rather than die in terms of the provision of health care:

- The decentralization and rationalization of the administration of health care.

- The stress on and realization of effective and efficient primary health care.

- The acceptance of participative management in health providing organizations.

- The provision of financial management training for health care managers.

- The application of management accounting principles and developments, for example zero-based-budgeting, break-even analysis, participative budgets, responsibility accounting, activity-based costing $(\mathrm{ABC})$, activity-based budgeting and management and workforce activity-based management (WABM) is crucial to the improvement of the efficiency and effectiveness of management.

\section{REFERENCES}

Anon. (1994a). Healthcare: The end of elitism Finance week, 60(3), 5-7, Jan. 20-26.

Anon. (1994b). ANC health policy: Changing the emphasis. Financial Mail, 131(5), 26-27, Feb. 4.

Anon. (1994c). Health care booster. Financial Mail, 132(13), 26, Jun. 24

ANC. (1994). A national health plan for South Africa . Maseru: Bähr Mapping.

Covey, S.R. (1994). The 7 habits of highly effective people. New York: Simon \& Schuster.

Department of health and developmental social welfare. (1995a). Drafi white paper on healih North West Province.

Department of health and developmental social welfare. (1995b). Working Docu-ment on health - First draft. North West Province.

Department of bealth and developmental social welfare. (1995c). 5 Year budget plan 1995/96 to 1999/2000-North West Province.

Ferrinho, P de L. G. (1994). Hospital care in the North West Province of South Africa. Report.

Finlayson, J. (1994). Healing new wounds. Marketing Mix, 12(5), 69-72.

Garrison, R.H. \& Noreen, E.W. (1994). Managerial Accounting. London: Chapman \& Hall.

Geischecker, M.L. (1996). New Technologies support ABC. Managemens Accounting, $77(9)$, $42-48$.

Gibson, J.L., Ivancevich, J.M. \& Donnelty, E.W. (1991). Organizations : Behavior. Sinucrure. Processes. Boston: Homewood. 
Kharbanda, O.P. \& Stallworthy, E.A. (1991) Lets' learn from Japan. Manogement Accounting, 69(3), 26-30

Liebenberg, C. (1996). Begroting '96. Finansies en Tegniek, 48(11), 1-15, Bylae, Mrt. (Translated : Budgeting '96).

Rayburn, L.G. (1996). Cost Accounting : Using a cost management approach. USA : Irwin.

Robb, D. (1995). Health care in the North West Province. (Interview on tape).

Smith, C. (1994). Get well soon. Finance week, 63(5), 16-19.

Stewart, J. (1992). Budget freeze. Finance week, $55(1), 28,1-7$.
Stewart, J. (1994). What's up, doc? Finance week $62(1), 18-19$

Turney, P.B.B. (1993). Beyond TQM with workforce activity-based management. Management Accounting, 75(3), 28-31.

Viljoen, M. (1994). Die toepassing van aktiwiteitsgebaseerde kosteberekening in privaathospitale in Suid-Afrika (Translated The application of activity-based costing in private hospitals in South Africa.) M. Com -dissertation. Potchefstroom University for CHE.
Sarah S. Visser (Professor)

D.Com, UED, DTE

Department of Cost and Management Accounting

Potchefstroom University for CHE

Albè H. Nel

Ph.D

Nursing Management

Department of Nursing

Potchefstroom University for CHE

Erkenning word gegee aan die Sentrum vir Wetenskapsontwikkeling (SWO) vir finansiële ondersteuning. 